\title{
Synchronous splenic metastasis of endometrial carcinoma
}

\author{
António Pedro Pissarra, ${ }_{1}^{1}$ Teresa Margarida Cunha, ${ }^{2}$ Sara Mata ${ }_{1}^{3}$ Ana Félix ${ }^{3}$
}

'Department of Radiology, Hospitais da Universidade de Coimbra, Coimbra, Portugal ${ }^{2}$ Department of Radiology, Instituto Português de Oncologia de Lisboa Francisco Gentil, Lisbon, Portugal ${ }^{3}$ Department of Pathology, Instituto Português de Oncologia de Lisboa Francisco Gentil, Lisboa, Portugal

Correspondence to Dr António Pedro Pissarra, antoniopedropissarra@gmail. com

Accepted 30 May 2019
Check for updates

(c) BMJ Publishing Group Limited 2019. No commercial re-use. See rights and permissions. Published by BMJ.

To cite: Pissarra AP, Cunha TM, Mata S, et al. BMJ Case Rep 2019:12:e230957. doi:10.1136/bcr-2019230957

\section{DESCRIPTION}

A 70-year-old patient presented in October 2016 with postmenopausal vaginal bleeding associated with diffuse abdominal pain, especially in the lower abdomen. She underwent clinical and ultrasound evaluation and hysteroscopy with endometrial biopsy, with pathological result of endometrioid grade 3 endometrial carcinoma.

MR staging did not reveal deep myometrial invasion or pelvic adenomegalies (figure 1A-D), but a splenic tumour was depicted (figure 1E,F). A Positron Emission Tomography (PET) scanwas ordered and did not show other lesions (figure 1G). Considering the rarity of the diagnosis of solitary splenic metastasis, with about 100 cases described in the literature (half of which originated from female genital tract tumours, most often from ovarian neoplasms, with only 13 cases described in the context of endometrial carcinoma), ${ }^{1}$ the hypothesis of splenic angiosarcoma was primarily considered. However, spleen biopsy (performed in December 2016; figure 2A) confirmed the diagnosis of a solitary spleen metastasis from endometrial carcinoma.

In February 2017, the patient underwent total hysterectomy with bilateral salpingo-oophorectomy (figure 2B) and concomitant splenectomy (figure $2 \mathrm{C}$ ). In macroscopic pathology, the spleen was $18 \times 11 \times 11 \mathrm{~cm}$ in size with a solid tumour

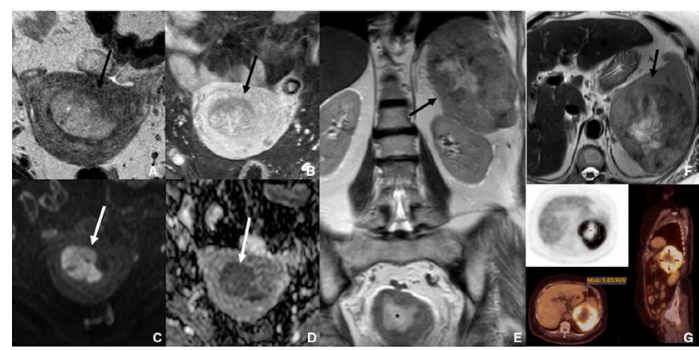

Figure 1 Axial T2-weighted (A), axial oblique contrastenhanced three-dimensional gradient echo image with fat suppression after contrast injection (B) and diffusion-weighted imaging $(C, D=1000)$ with apparent diffusion coefficient map (D) MR images of the uterus show the endometrial tumour (black arrows in $A$ and $B$, white arrows in $C$ and $D$ ) hyperintense and with less enhancement relatively to normal endometrium, without extension to the outer myometrium. Coronal T2weighted image (E) shows a splenic tumour (black arrow) synchronous with the endometrial carcinoma $\left({ }^{*}\right)$. Axial T2 (F) image depicts the large splenic lesion (black arrow), also detected in the positron emission tomography (PET) $\operatorname{scan}(G)$.

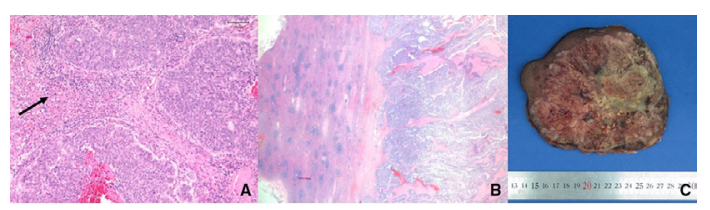

Figure 2 High-power $(\times 200)$ histological section stained with $\mathrm{H} \& \mathrm{E}$ shows an intraparenchymal metastasis of a poorly differentiated endometrioid carcinoma; black arrow in the red pulp of the spleen $(A)$; endometrial carcinoma invading the myometrium (H\&E) (B); gross specimen of the spleen after splenectomy depicts a large mass in the spleen, extending to the margins of the specimen, with diffuse infiltration of the parenchyma (C).

measuring $12 \mathrm{~cm}$, with the postoperative diagnosis of spleen metastasis of endometrial origin.

Endometrial carcinoma is the most common gynaecological cancer in developed countries. Spleen metastasis is very uncommon (usually secondary to lung and breast cancers), and solitary spleen metastasis from endometrial carcinoma is even rarer. When secondary to endometrial carcinoma, they were found to be metachronous in relation to the diagnosis of endometrial carcinoma, solitary and limited to the parenchyma. ${ }^{2}$ To the best of our knowledge, the case we present is the first where the splenic metastasis was synchronous with the endometrial carcinoma diagnosis.

Spleen metastasis has no specific symptoms, emphasising the importance of including the upper abdomen when performing radiological studies for cancer staging and follow-up. ${ }^{3}$

\section{Patient's perspective}

I am glad to share my case, realising that it is rare and I think it was a diagnostic and therapeutic success. I hope that by sharing my case I can help other patients in the future, who find themselves in situations similar to mine.

\section{Learning points}

Solitary spleen metastasis can rarely occur and can be assessed by image-guided biopsy.

- Radiology must include upper abdomen sequences in the initial high-grade endometrial cancer staging.

- Splenectomy is the best treatment option in cases of solitary metastasis. 
Images in...

The patient is alive without signs of recurrence, 14 months after splenectomy and six cycles of chemotherapy (paclitaxel and carboplatin).

Contributors APP wrote the article and together with TMC interpreted the MRI scan. SM and AF made the pathological evaluation and provided the microscopic and macroscopic pictures.

Funding The authors have not declared a specific grant for this research from any funding agency in the public, commercial or not-for-profit sectors.

Competing interests None declared.

Patient consent for publication Obtained.

Provenance and peer review Not commissioned; externally peer reviewed.

\section{REFERENCES}

1 Arif A, Abideen ZU, Zia N, et al. Metastatic involvement of the spleen by endometrial adenocarcioma; a rare asylum for a common malignancy: a case report. BMC Res Notes 2013;6:476.

2 Piura B, Rabinovich A, Apel-Sarid L, et al. Splenic metastasis from endometrial carcinoma: report of a case and review of literature. Arch Gynecol Obstet 2009;280:1001-6.

3 Nougaret S, Horta M, Sala E, et al. Endometrial Cancer MRI staging: Updated Guidelines of the European Society of Urogenital Radiology. Eur Radiol 2019;29:792-805

Copyright 2019 BMJ Publishing Group. All rights reserved. For permission to reuse any of this content visit

https://www.bmj.com/company/products-services/rights-and-licensing/permissions/

BMJ Case Report Fellows may re-use this article for personal use and teaching without any further permission.

Become a Fellow of BMJ Case Reports today and you can:

- Submit as many cases as you like

- Enjoy fast sympathetic peer review and rapid publication of accepted articles

- Access all the published articles

Re-use any of the published material for personal use and teaching without further permission

\section{Customer Service}

If you have any further queries about your subscription, please contact our customer services team on +44 (0) 2071111105 or via email at support@bmj.com.

Visit casereports.bmj.com for more articles like this and to become a Fellow 